\title{
The impact of theta-burst stimulation on cortical GABA and glutamate in treatment-resistant depression: A surface-based MRSI analysis approach
}

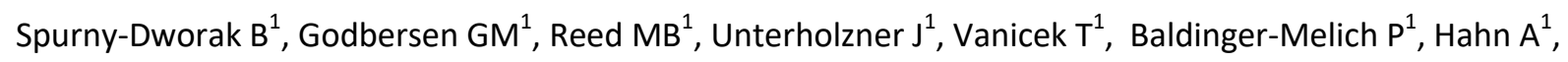

$$
\text { Kranz } \mathrm{GS}^{1,2} \text {, Bogner } \mathrm{W}^{3} \text {, Lanzenberger } \mathrm{R}^{1 *} \text {, Kasper } \mathrm{S}^{1,4} *
$$

${ }^{1}$ Department of Psychiatry and Psychotherapy, Medical University of Vienna, Austria ${ }^{2}$ Department of Rehabilitation Sciences, The Hong Kong Polytechnic University, Hung Hom, Hong Kong ${ }^{3}$ Department of Biomedical Imaging and Imageguided Therapy, High Field MR Centre, Medical University of Vienna, Austria ${ }^{4}$ Department of Molecular Neuroscience, Center for Brain Research, Medical University of Vienna, Austria

For submission to

medRxiv

\begin{tabular}{|c|l|}
\hline \multicolumn{2}{|c|}{ word count } \\
\hline 250 & abstract \\
\hline 1223 & introduction \\
\hline 966 & discussion \\
\hline Number of pages: 19, Tables: 2, Figures: 7 \\
\hline
\end{tabular}

Key words: TBS, MRS, GABA, glutamate, depression, TMS

Abbreviated title: Impact of TBS on cortical GABA and glutamate in TRD

* Correspondence to:

Prof. Rupert Lanzenberger, MD PD

Department of Psychiatry and Psychotherapy, Medical University of Vienna, Waehringer Guertel 1820, 1090 Vienna, Austria rupert.lanzenberger@meduniwien.ac.at http://www.meduniwien.ac.at/neuroimaging/

\section{Prof. Siegfried Kasper, Dr.hc.mult. MD}

Center for Brain Research, Medical University of Vienna, Waehringer Guertel 18-20, 1090 Vienna, Austria siegfried.kasper@meduniwien.ac.at 
medRxiv preprint doi: https://doi.org/10.1101/2022.02.17.22271118; this version posted February 21, 2022. The copyright holder for this preprint (which was not certified by peer review) is the author/funder, who has granted medRxiv a license to display the preprint in

All rights reserved. No reuse allowed without permission.

\begin{abstract}
Background: Theta burst stimulation (TBS) belongs to one of the biological antidepressant treatment options. When applied bilaterally, excitatory intermittent TBS (iTBS) is commonly targeted to the left and inhibitory continuous TBS (CTBS) to the right dorsolateral prefrontal cortex. TBS was shown to influence neurotransmitter systems, while iTBS is thought to interfere with glutamatergic circuits and cTBS to mediate GABAergic neurotransmission.
\end{abstract}

Objectives: We aimed to expand insights in the therapeutic effects of TBS on the GABAergic and glutamatergic system utilizing 3D-multivxovel magnetic resonance spectroscopy imaging (MRSI) in combination with a novel surface-based MRSI analysis approach to investigate changes of cortical neurotransmitter levels in patients with treatment resistant depression (TRD).

Methods: Twelve TRD patients ( 5 female, mean age $\pm S D=35 \pm 11$ years) completed paired MRSI measurements, using a GABA-edited 3D-multivoxel MEGA-LASER sequence, before and after three weeks of bilateral TBS treatment. Changes in cortical distributions of GABA+/tNAA (GABA+macromolecules relative to total $\mathrm{N}$-acetylaspartate) and Glx/tNAA (Glx=mixed signal of glutamate and glutamine), were investigated in a surface-based region-of-interest (ROI) analysis approach.

Results: ANCOVAs revealed a significant increase in GIx/tNAA ratios in the left caudal middle frontal area $\left(p_{\text {corr }}=0.046, F=13.292\right)$, an area targeted by iTBS treatment. Whereas, contralateral treatment with cTBS evoked no alterations in glutamate or GABA concentrations.

Conclusion: This study demonstrates surface-based adaptions in the stimulation area to the glutamate metabolism after excitatory iTBS but not after cTBS, using a novel surface-based analysis of 3D-MRSI data. The reported impact of facilitatory iTBS on glutamatergic neurotransmission provides further insight into the neurobiological effects of TBS in TRD. 
medRxiv preprint doi: https://doi.org/10.1101/2022.02.17.22271118; this version posted February 21, 2022. The copyright holder for this preprint (which was not certified by peer review) is the author/funder, who has granted medRxiv a license to display the preprint in All rights reserved. No reuse allowed without permission.

\section{Introduction}

Major depressive disorder (MDD) represents a severe psychiatric disease affecting up to $3.8 \%$ of the population worldwide and has risen further during the last years (Collaborators, 2021). Several treatment options of pharmacological (e.g. selective serotonin reuptake inhibitors (SSRIs) or ketamine) or non-pharmacological, biological interventions (i.e. transcranial magnetic stimulation (TMS) or electroconvulsive therapy (ECT)) are currently available. Modifications of neurotransmitter systems are key aspects in the antidepressant actions of different interventions in order to restore GABAergic or glutamatergic function (Kalueff and Nutt, 2007; Sanacora, 2012). Several studies have shown SSRIs or ketamine to affect a variety of neurotransmitter systems including the serotonergic (Spindelegger, 2009; Hahn, 2010; Lanzenberger, 2012), GABAergic (Sanacora, 2002; Brennan, 2017; Silberbauer, 2020) or the glutamatergic system (Rowland, 2005; Taylor, 2008; Spurny, 2021). Moreover, certain antidepressants directly interfere with the glutamatergic or GABAergic system. The N-methyl-D-aspartate (NMDA) receptor antagonist ketamine is a treatment option for the use in TRD patients, leading to rapid symptom reductions (Kasper, 2021; McIntyre, 2021). Although ketamine is targeting the glutamatergic system, adaptions in GABA levels could be reported (Silberbauer, 2020). According to a recent study, the clinical efficacy in TRD of rTMS does not differ from ketamine (Mikellides, 2021). Another promising treatment option for TRD (currently under clinical investigation) is zuranolone a modulator of the $G_{A B A}$ receptor (Gunduz-Bruce, 2019). Hence, both the glutamatergic and GABAergic system are promising targets for the treatment of TRD.

While the biological binding sites and downstream effects of pharmacological interventions are abundantly studied, this is oftentimes less clear for non-pharmacological, biological treatments. ECT is known to induce a remodeling of functional networks ( $Q i, 2020$ ) and alterations across the serotonergic and GABAergic system (Sanacora, 2003; Baldinger, 2014).

Since TBS has fewer side effects compared to ECT, it finds broader acceptance in patients especially in treatment resistant depression (TRD). When two different pharmacological treatment trials fail to significantly improve clinical symptoms, MDD is commonly classified as TRD, although this definition varies between studies (Gaynes, 2020). In a meta-analysis of 29 randomized, double-blind and shamcontrolled trials, Berlim et al. demonstrated response and remission rates of $29 \%$ and $19 \%$ of subjects with major depression receiving excitatory high-frequency TMS (Berlim, 2014). Thereby, typically bihemispheric theta burst stimulation (TBS) is applied using excitatory intermittent (iTBS) or inhibitory continuous TBS (cTBS) to the dorsolateral prefrontal cortex (DLPFC). The DLPFC was shown to provide a suitable target for TBS to treat TRD (George, 1995). 
medRxiv preprint doi: https://doi.org/10.1101/2022.02.17.22271118; this version posted February 21, 2022. The copyright holder for this preprint (which was not certified by peer review) is the author/funder, who has granted medRxiv a license to display the preprint in All rights reserved. No reuse allowed without permission.

Previous imaging studies reported diverse effects of TMS on different morphological and physiological parameters. Stimulation of the DLPFC was reported to affect functional connectivity between the PFC and cingulate regions (Baeken, 2014; Salomons, 2014). Similar to pharmacological treatments, TMS was shown to evoke changes in neurotransmitter systems in both animal and human studies. Two ${ }^{1} \mathrm{H}$-MRS studies found correlations of glutamate levels in the motor cortex and excitability with TMS (Stagg, 2009; Tremblay, 2013). In disease, a study by Pogarell et al. revealed adaptions in the dopaminergic system in MDD patients following repetitive TMS (rTMS) treatment (Pogarell, 2006). Furthermore, an investigation by Lewis et al. reported changes in cortical excitability in patients suffering from MDD in the primary motor cortex and the ACC (Lewis, 2016). Dubin et al. were one of the first to investigate the therapeutic effect of TMS on neurotransmitter distribution using MRS, showing elevated GABA levels (Dubin, 2016). However, effects on the glutamatergic system in MDD are less conclusive and similar to GABA limited to a handful studies. While Dubin and colleagues reported no effects on glutamate in the PFC, a different approach revealed elevations in the glutamate/glutamine (Glu/Gln) ratio after TMS treatment in MDD patients (Croarkin, 2016; Dubin, 2016).

However, impacts on neurotransmitter levels seem to differ between intermittent and continuous TBS with studies reporting inconclusive findings. Iwabuchi et al. showed reduced GABA/Glx levels in the DLPFC and ACC after iTBS to the left DLPFC (Iwabuchi, 2017). Moreover, increased GABA concentrations in the PCC after iTBS to the left inferior parietal lobe could be revealed (Vidal-Pineiro, 2015). In addition iTBS was described to increase the N100 amplitude (a marker for GABA-mediated inhibition), while cTBS reduced this amplitude in the cerebellum of healthy individuals (Harrington and Hammond-Tooke, 2015). On the other hand, cTBS, applied to the motor cortex, was reported to increase GABA concentrations while no effects were shown on glutamate (Stagg, 2009) suggesting an enhancement of interneural circuits. Based on the evidence of preclinical and clinical studies in animals and humans, Li et al. proposed a model to explain differential aftermaths of intermittent and continuous TBS on GABA and glutamate (Li, 2019). This model suggests iTBS to inhibit GABAergic interneurons, which in consequence leads to reduced inhibition of glutamatergic pyramidal cells, while continuous bursts of cTBS might increase the inhibitory activities of interneurons resulting in higher GABA concentrations.

However, due to the inconclusive evidence of the potential of TBS to restore disrupted GABAergic and glutamatergic neurotransmission in TRD subjects further research is needed. Since previous findings of MRS studies were restricted to a limited number of locations by the use of single voxel sequences, we aimed to extend our understanding by applying a 3D-multivoxel MRSI approach to cover a range of cortical regions, involved in the pathophysiology of MDD. Due to the cortical 
medRxiv preprint doi: https://doi.org/10.1101/2022.02.17.22271118; this version posted February 21,2022 . The copyright holder for this preprint (which was not certified by peer review) is the author/funder, who has granted medRxiv a license to display the preprint in

All rights reserved. No reuse allowed without permission.

stimulation method of TBS, changes within these regions are of high interest. Hence, we applied a novel surface-based analysis approach of multi-voxel MRS data, based on a similar method used in PET imaging (Greve, 2014). We investigated adaptions in cortical GABA+/tNAA (GABA+ = a combination of GABA and macromolecules; tNAA= total N-acetylaspartate) and Glx/tNAA (Glx = combined signal of glutamate and glutamine) after three weeks of iTBS to left and cTBS treatment to the right DLPFC in a cohort of TRD patients.

\section{Methods}

\subsection{Study design}

All study patients underwent three weeks of TBS treatment at the Department of Psychiatry and Psychotherapy at the Medical University of Vienna, Austria. MRSI measurements were conducted within 2 weeks prior to and after the TBS treatment period (see Figure 1). This study was approved by the Ethics Committee of the Medical University of Vienna (EK 1761/2015) and part of a larger clinical trial with multimodal neuroimaging (ClinicalTrials. gov Identifier: NCT02810717).

\subsection{Participants}

Twelve TRD patients ( 5 female, mean age \pm SD $=35 \pm 11$ years) with a DSM-4 diagnosis of single or recurrent MDD were included in our analysis. TRD was defined as insufficient response to two treatment trials in adequate dosage and time ( $>4$ weeks) according to the criteria set by the GSRD group (Group for the studies of Resistant Depression) (Bartova, 2019). Moreover, participants were included if they had a HAMD-17 total score of $\geq 18$, a Clinical Global Impression Scale score of $\geq 4$ and a stable treatment regime of 4 weeks prior to the study inclusion, which remained unchanged during the study participation. Exclusion criteria included psychotic symptoms, severe internal illnesses within the last 5 years, neurological diseases or brain injuries, substance abuse left handedness, or any contraindications to TMS treatment and MRI.

\subsection{Transcranial magnetic stimulation}

Over the course of three weeks, patients received intermittent (stimulating) TBS (iTBS) to the left DLPFC and continuous (inhibiting) TBS (CTBS) to the right DLPFC. iTBS consisted of 2-second trains (30 pulses; 10 bursts) repeated 20 times (600 pulses per session). cTBS comprised uninterrupted bursts of 600 pulses per session (see Figure 1). The TBS protocol was performed similar to Huang et al. (3pulse $50-\mathrm{Hz}$ bursts delivered at $5 \mathrm{~Hz}$ ) by using a MagPro magnetic stimulator (MagVenture, Denmark K) and a figure-of-eight shaped cool coil (Cool-B70) (Huang, 2005). Daily treatment (5 days per week) 
medRxiv preprint doi: https://doi.org/10.1101/2022.02.17.22271118; this version posted February 21, 2022. The copyright holder for this preprint (which was not certified by peer review) is the author/funder, who has granted medRxiv a license to display the preprint in All rights reserved. No reuse allowed without permission.

included two TBS sessions, separated by one hour, which were reversed for consecutive sessions (Li, 2014). The stimulation area (DLPFC) was defined in Montreal Neurological Institute (MNI) space (coordinates: $[-38,+44,+26]$ - left DLPFC; $[+38,+44,+26]$ - right DLPFC), using neuro-navigation (LOCALITE ${ }^{\circledR}$ TMS Navigator Germany), based on individual structural MRIs of each participant (Hecht, 2010). Stimulation intensity was based on $120 \%$ of the individual resting motor threshold (Ge, 2017).

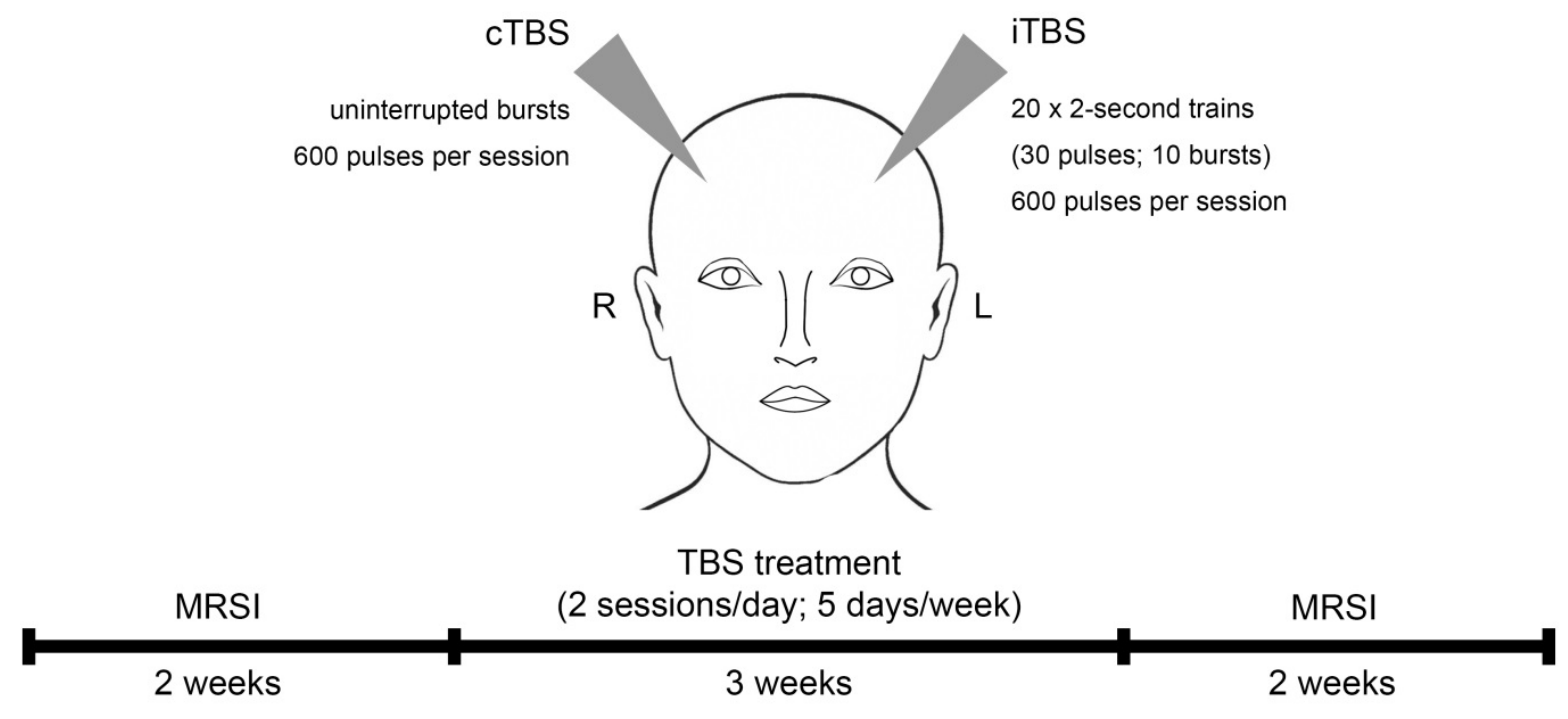

Figure 1: Study design and treatment regime. Study subjects received theta burst stimulation (TBS) over 3 weeks including 2 stimulations a day for 5 days per week. TBS sessions comprised intermittent TBS (iTBS) to the left and continuous TBS (cTBS) to the right dorsolateral prefrontal cortex. Magnetic resonance spectroscopy imaging (MRSI) measurements were conducted within 2 weeks before and after the treatment period.

\subsection{Magnetic resonance spectroscopy}

MRI measurements were performed on a 3 Tesla MAGNETOM Prisma Siemens MR Scanner using a 64-channel head coil. For accurate volume of interest (VOI)-placement and surface extraction, 3D T1weighted anatomical images were acquired via a MPRAGE sequence (208 slices, 288x288 matrix size, voxel size $1.15 \times 1.15 \times 0.85 \mathrm{~mm}^{3}$ ) with GRAPPA acceleration. For MRS, a constant-density, spiralencoded, 3D-MRSI sequence with MEGA-LASER editing (Bogner, 2014) was used with a VOI = $110 \times 120 \times 45 \mathrm{~mm}^{3}$ and field of view $(F O V)=160 \times 160 \times 160 \mathrm{~mm}^{3}$. The acquired matrix size of $10 \times 10 \times 10$ (approx. $4 \mathrm{~cm}^{3}$ voxel size) was interpolated to a $16 \times 16 \times 16$ matrix (approx. $1 \mathrm{~cm}^{3}$ voxel size) during 
medRxiv preprint doi: https://doi.org/10.1101/2022.02.17.22271118; this version posted February 21, 2022. The copyright holder for this preprint (which was not certified by peer review) is the author/funder, who has granted medRxiv a license to display the preprint in perpetuity.

All rights reserved. No reuse allowed without permission.

spectral processing steps. Since the VOI was placed close to the skull to cover cortical regions, tissue saturation slabs ( $25 \mathrm{~mm}$ thickness, sat. delta frequency: $-3.5 \mathrm{ppm}$ ) were used to suppress signals from subcutaneo jjus lipids (see Figure 2). Siemens advanced shimming procedure with manual adjustments was used. During the EDIT-ON acquisition, MEGA -editing pulses (60 Hz Gaussian pulses of 14.8 ms duration) were set to $1.9 \mathrm{ppm}$, editing the coupled $4 \mathrm{CH}_{2}$ triplet of $\mathrm{GABA}$ resonating at 3.02 ppm. 24 acquisition-weighted averages and two -step phase cycling were employed for 3D-MRSI, resulting in a total scan time of 17:23 min.

An in-house software tool using MATLAB (R2013a, MathWorks, Natick, MA, USA), Bash (4.2.25, Free Software Foundation, Boston, MA, USA), MINC (2.0, MINC Tools, McConnell Brain Imaging Center, Montreal, QC, Canada) and LCModel software (6.3-1, S. Provencher, LCModel, Oakville, ON, Canada) was used for the quantification of all spectra within the VOI (Spurny, 2019). A simulated basis sets was created using the GAMMA library for the difference spectrum (containing GABA+, Glx and tNAA among others, (Hnilicova, 2016)). An exemplary spectrum is shown in supplement figure 1. CramérRao lower bounds (CRLB) thresholds were set at 30\% and spectra were visually inspected.

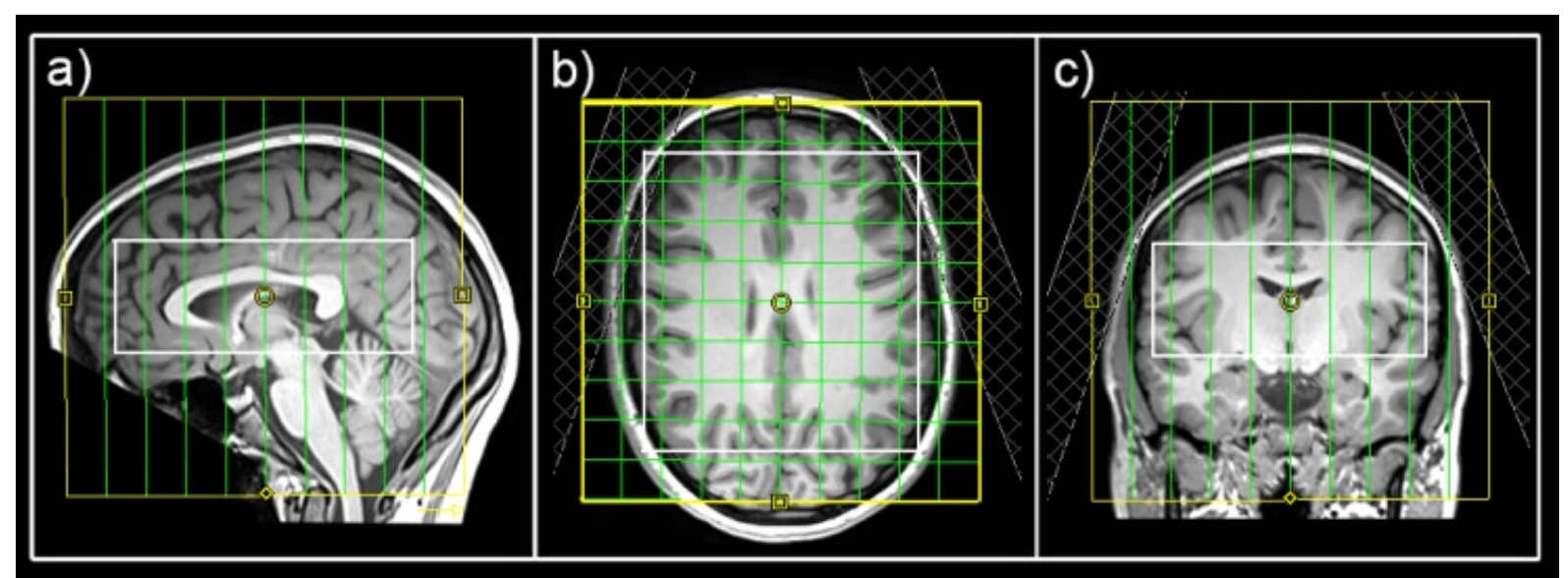

Figure 2: Placement of the field of view (yellow), volume of interest (white) and tissue separation slaps in sagittal (a), horizontal (b) and coronal (c) view.

\subsection{Surface-based MRSI analysis}

For surface-based quantification, metabolic maps of GABA+, Glx and tNAA were interpolated to the resolution of anatomical images and ratio maps of GABA+/tNAA and Glx/tNAA were calculated. Ratios to tNAA were favored over total creatine ( $\mathrm{tCr}$ ), since changes in $\mathrm{tCr}$ after rTMS treatment were previously reported (Grohn, 2019). FreeSurfer 6.0 (https://surfer.nmr.mgh.harvard.edu/) was used for the surface-based analysis approach of MRSI data. Previous investigations have successfully shown cortical analysis approaches of metabolic maps in FreeSurfer using positron emission tomography (PET) data (Greve, 2014). Hence, this analysis was based on previous reports. Individual 
medRxiv preprint doi: https://doi.org/10.1101/2022.02.17.22271118; this version posted February 21, 2022. The copyright holder for this preprint (which was not certified by peer review) is the author/funder, who has granted medRxiv a license to display the preprint in perpetuity.

All rights reserved. No reuse allowed without permission.

ratio maps of single subjects were spatially normalized by projecting onto the standard surface (fsaverage) using the tkregister 2 command. All vertices of individual surfaces were assigned to the corresponding region-of-interest (ROI) using the Desikan atlas (Desikan, 2006). The following ROIs were included in the analysis: superiorfrontal, rostral middle frontal, caudal middle frontal, pars opercularis and precentral for both GIx/tNAA and GABA+/tCr and additionally pars triangularis, postcentral, paracentral, posterior cingulate and caudal anterior cingulate for GIx/tNAA ratios only, due to insufficient data quality in GABA+ maps. Furthermore, each surface was filtered by removing vertices that did not pass the CRLB threshold or laid above twice the standard variation within its respective brain region. After filtering steps, all remaining vertices were averaged within each ROI. Group-wise comparisons between measurements were done with calculated mean cortical neurotransmitter ratios within ROls of each subject.

\subsection{Statistical analysis}

Statistical analyses were performed using SPSS Statistics (v26.0, 2010, SPSS, Inc., an IBM Company, Chicago, United States of America). Two-tailed paired t-tests were conducted to test for differences in HAM-D measures before and after the treatment period $(p<0.025)$. Univariate analyses of covariance (ANCOVAs) including sex and age as covariates were performed for each ROI and neurotransmitter ratio independently, to test for differences between measurements. Sidak correction was applied to correct for multiple comparisons (ROIs * neurotransmitter ratios, Table 1). Residuals were tested for normal distribution using the Kolmogorov-Smirnoff test. 
medRxiv preprint doi: https://doi.org/10.1101/2022.02.17.22271118; this version posted February 21, 2022. The copyright holder for this preprint (which was not certified by peer review) is the author/funder, who has granted medRxiv a license to display the preprint in All rights reserved. No reuse allowed without permission.

\section{Results}

All twelve TRD patients ( 5 female, mean age $\pm S D=35 \pm 11$ years) completed both MRSI measurements. Detailed stable pharmacological treatment of the patient cohort can be found in supplement table 1. HAM-D measures showed significant reductions after the treatment period $(19.9 \pm 2.8$ before treatment to $12 \pm 6.8$ post treatment (mean $\pm S D), p=0.002$ ) with a response rate of $33 \%$ (HAM-D reductions $\geq 50 \%$ ) and remission rate of $25 \%$ (HAM-D $<7$ ) of the TRD patients.

Due to insufficient data quality of GABA+ maps in the right superiofrontal area, this ROI had to be excluded resulting in a total of 29 ROIs in the final analysis (see Table 1). Hence, results from ANCOVAs were corrected for 29 comparisons using the Sidak correction method.

Table 1: ROIs of each hemisphere included in the analysis of GIx/tNAA and GABA+/tNAA ratios. Glx = combined measure of glutamate and glutamine; tNAA = total N-acetylaspartate; GABA+ = a combination of GABA and macromolecules.

\begin{tabular}{|l|c|c|c|c|}
\cline { 2 - 5 } \multicolumn{1}{c|}{} & \multicolumn{2}{c|}{ GIx/tNAA } & \multicolumn{2}{c|}{ GABA+/tNAA } \\
\hline ROI & left & right & left & right \\
\hline superiorfrontal & $\mathrm{x}$ & $\mathrm{x}$ & $\mathrm{x}$ & \\
\hline rostral middle frontal & $\mathrm{x}$ & $\mathrm{x}$ & $\mathrm{x}$ & $\mathrm{x}$ \\
\hline caudal middle frontal & $\mathrm{x}$ & $\mathrm{x}$ & $\mathrm{x}$ & $\mathrm{x}$ \\
\hline pars opercularis & $\mathrm{x}$ & $\mathrm{x}$ & $\mathrm{x}$ & $\mathrm{x}$ \\
\hline pars triangularis & $\mathrm{x}$ & $\mathrm{x}$ & & \\
\hline precentral & $\mathrm{x}$ & $\mathrm{x}$ & $\mathrm{x}$ & $\mathrm{x}$ \\
\hline postcentral & $\mathrm{x}$ & $\mathrm{x}$ & & \\
\hline paracentral & $\mathrm{x}$ & $\mathrm{x}$ & & \\
\hline posterior cingulate & $\mathrm{x}$ & $\mathrm{x}$ & & \\
\hline caudal anterior cingulate & $\mathrm{x}$ & $\mathrm{x}$ & & \\
\hline
\end{tabular}

ANCOVAs revealed a significant difference in GIx/tNAA ratios in the left caudal middle frontal area $\left(p_{\text {corr }}=0.046, F=13.292\right)$, an area targeted by (excitatory) iTBS treatment. Boxplots illustrating mean GIx/tNAA ratios before and after the treatment are shown in figure 3 . No changes in GABA+/tNAA ratios could be detected in any ROI investigated. Although a cluster of elevated GABA+/tNAA ratios can be seen in the right caudal middle frontal area (see Figure $\mathbf{3} \mathbf{d}$ ), an area targeted with inhibitory cTBS, changes within this area did not reach statistical significance.

Changes in cortical GIx/tNAA and GABA+/tNAA are depicted in figure 4. Moreover, distributions of GIx/tNAA and GABA+/tNAA before and after the treatment are shown in figure $\mathbf{5}$ and supplement figure 2. 
medRxiv preprint doi: https://doi.org/10.1101/2022.02.17.22271118; this version posted February 21, 2022. The copyright holder for this preprint (which was not certified by peer review) is the author/funder, who has granted medRxiv a license to display the preprint in perpetuity.

All rights reserved. No reuse allowed without permission.

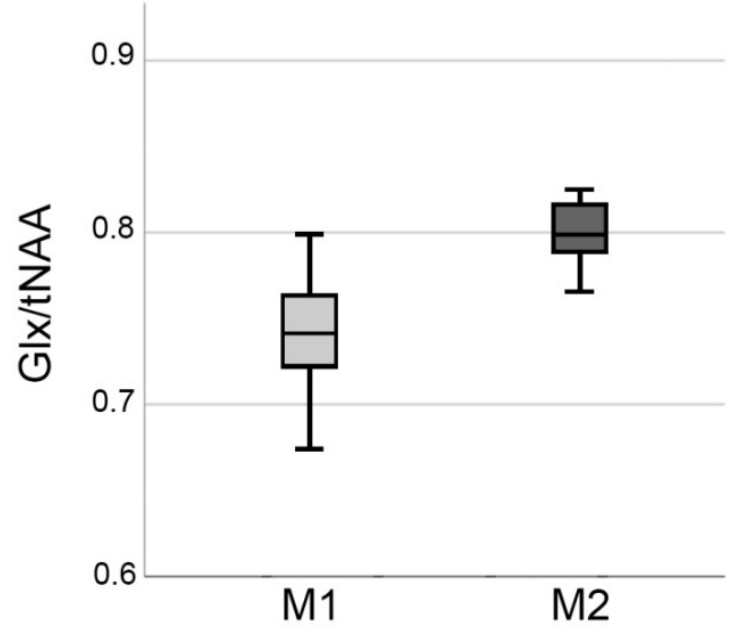

Figure 3: Boxplots showing elevations in Glx/tNAA ratio in the right caudal middle frontal area before (M1) and after the treatment period (M2). Glx = combined measure of glutamate and glutamine; tNAA = total N-acetylaspartate.

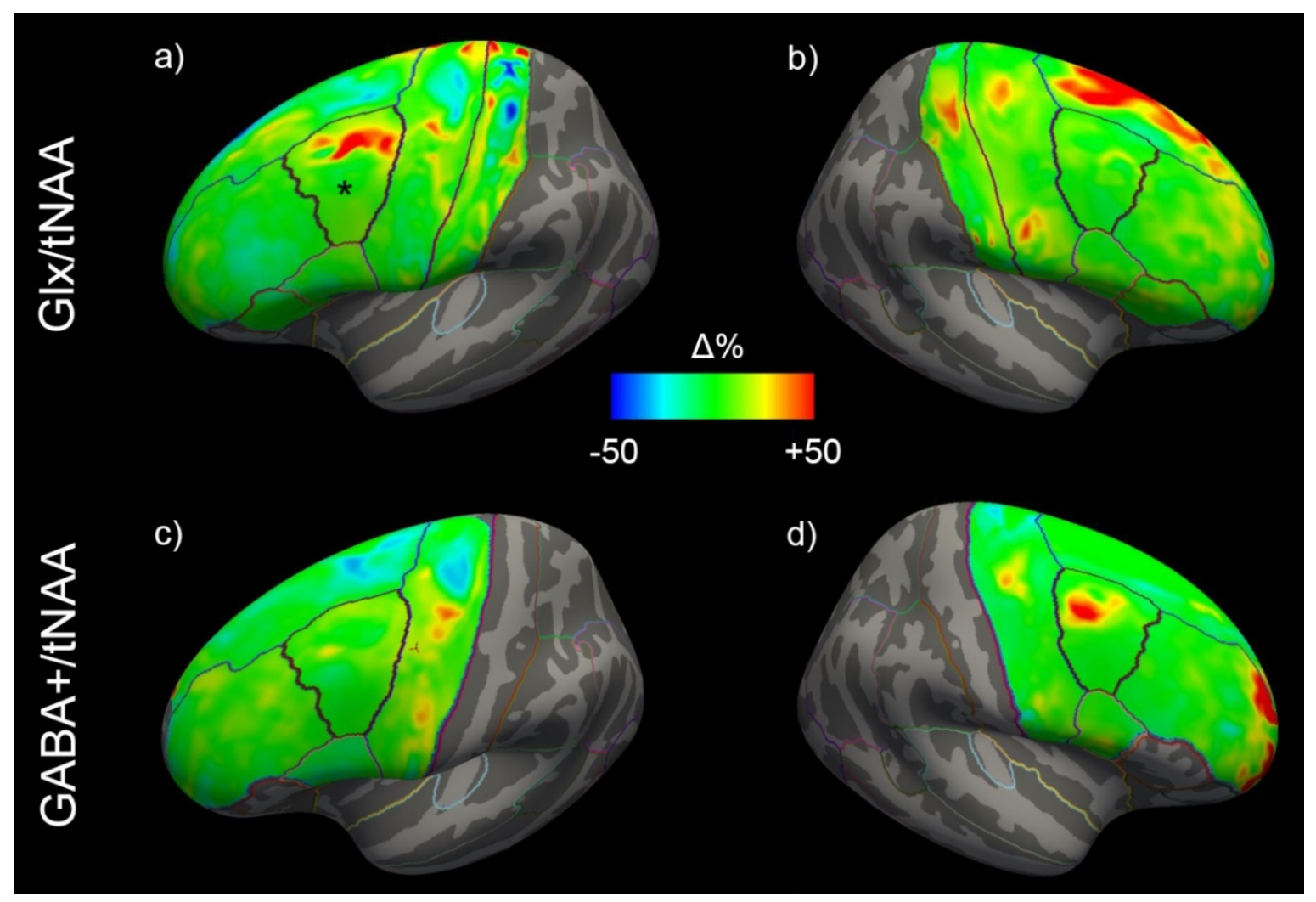

Figure 4: Mean changes of GIx/tNAA and GABA+/tNAA ratios of the left $(a, c)$ and right $(b, d)$ hemisphere across all study participants. The left caudal middle frontal area in (a), showing significant changes, is marked with $a *$. Glx = combined measure of glutamate and glutamine; tNAA = total N-acetylaspartate; GABA+ = a combination of GABA and macromolecules. 


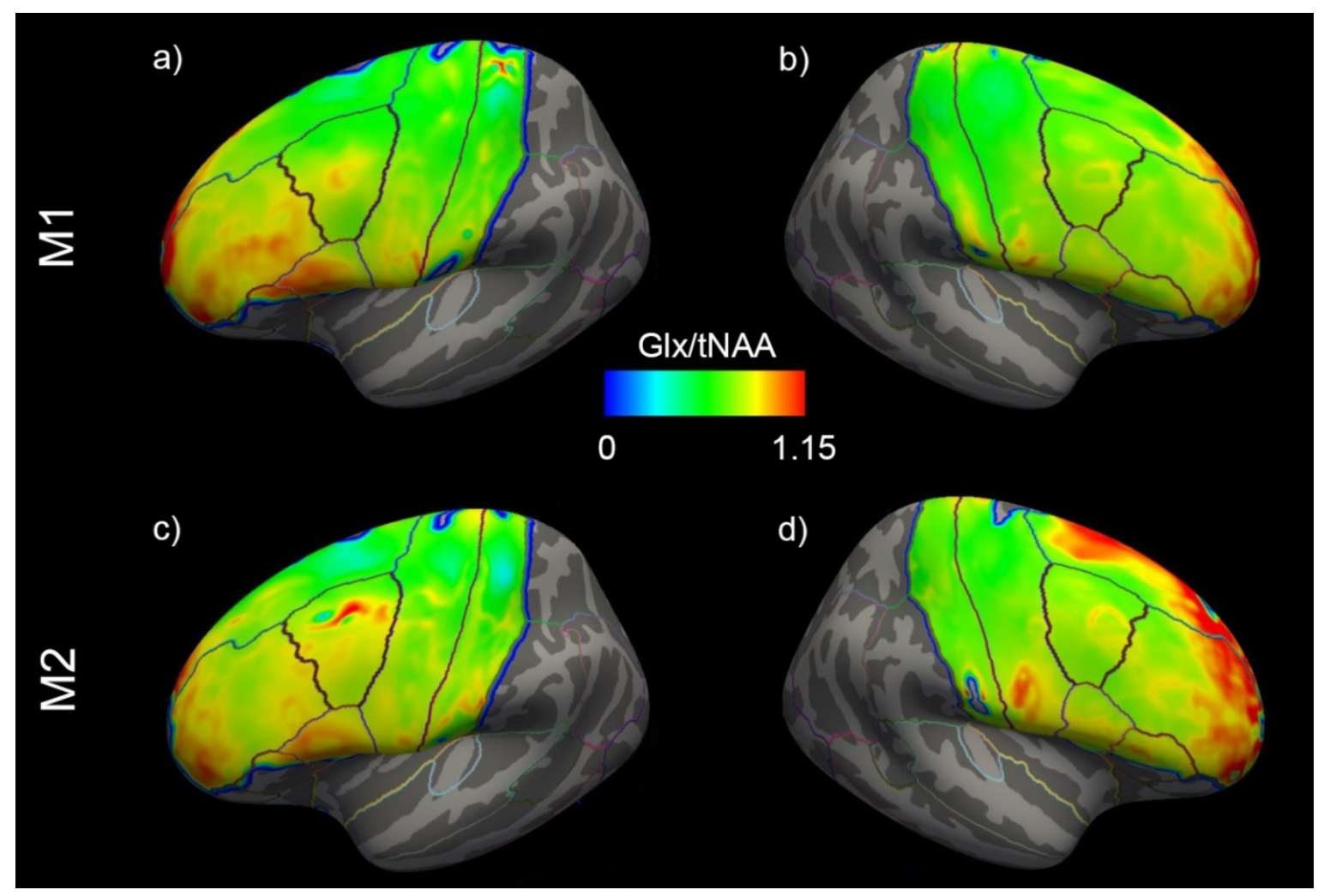

Figure 5: Mean distribution of Glx/tNAA ratios before $(=M 1)$ and after $(=M 2)$ the treatment period of the left $(a$ and $c$ ) and right $(b$ and $d)$ hemisphere. Glx = combined measure of glutamate and glutamine; tNAA = total $\mathrm{N}$-acetylaspartate. 
medRxiv preprint doi: https://doi.org/10.1101/2022.02.17.22271118; this version posted February 21, 2022. The copyright holder for this preprint (which was not certified by peer review) is the author/funder, who has granted medRxiv a license to display the preprint in All rights reserved. No reuse allowed without permission.

\section{Discussion}

Here we report elevated GIx/tNAA ratios in the left caudal middle frontal area after 3 weeks of TBS treatment in TRD patients using a surface-based MRSI analysis approach. Significant increases of Glx/tNAA were found in the left caudal middle frontal area after iTBS, while Glx/tNAA in the corresponding right area remained unchanged after cTBS. No changes in GABA+/tNAA ratios were revealed across the investigated cortical regions. Similar to previous surface-based PET analysis approaches (Greve, 2014), the proposed surface-based investigations of MRSI data provides a suitable tool when adaptions in neurotransmitter levels of cortical regions are expected, i.e. by utilizing cortical stimulation methods. Moreover, following the treatment, TRD patients experienced a marked reduction of HAM-D scores, a response rate of $\sim 33 \%$, and a remission rate of $\sim 25 \%$, which seems promising when compared to the $13.7 \%$ remission rate of the equivalent TRD patient collective in the third treatment step of the STAR*D study (Rush, 2006). Hence, the impact of the stimulation on neurotransmitters gives further insight into the neurobiological effects of TBS.

A dysregulation of glutamate, glutamine and GABA metabolism in MDD could be previously shown (Croarkin, 2011; Sanacora, 2012; Abdallah, 2014). Moreover, rTMS was assumed to directly influence these neurotransmitter systems. In line with (Croarkin, 2016), showing elevated glutamine/glutamate ratios in the anterior cingulate cortex and DLPFC, we found an increase of GIx/tNAA levels in the stimulation area of iTBS. Prior studies suggested a modulation of the glutamatergic system after rTMS demonstrating higher glutamate levels in both preclinical (Yue, 2009) and clinical studies (Michael, 2003). Moreover, Luborzewski et al. were able to show a link between clinical effectiveness of rTMS treatment to the DLPFC and glutamate elevations through rTMS therapy (Luborzewski, 2007). On a neurobiological level, rTMS is thought to alter synaptic connections and thereby affecting long-term potentiation (Fitzgerald, 2006). Hence, cTBS is suggested to lower synaptic strength, while iTBS leads to opposite effects in both GABAergic and glutamatergic cells (Huang, 2005; Huang, 2007). These findings highlight the importance of glutamate and its receptors to the physiological TBS response in the human brain (Huang, 2007; Ishikawa, 2007; Li, 2019). As proposed in the model by Li and colleagues, describing the neurophysiological effects of TBS treatment, the stimulating or facilitatory iTBS is thought to be accompanied by inhibition of GABAergic interneurons via feedforward inhibition leading to decreased suppression of glutamatergic cells (Li, 2019). In consideration of this model, our results demonstrate increased Glx/tNAA ratios in the stimulation area of iTBS. Hence, the decreased suppression of glutamatergic cells seems to be reflected in increased GIx/tNAA content, while the inhibition of interneurons was not reflected in altered GABA+/tNAA ratios. 
medRxiv preprint doi: https://doi.org/10.1101/2022.02.17.22271118; this version posted February 21, 2022. The copyright holder for this preprint (which was not certified by peer review) is the author/funder, who has granted medRxiv a license to display the preprint in

All rights reserved. No reuse allowed without permission.

On the other hand, inhibitory cTBS is speculated to activiate the I-1 pathway as well as leading to long-term depression by prolonged $\mathrm{Ca} 2+$ increases and thereby slowly increasing the activity of GABAergic interneurons (Li, 2019). This was supported by increased GABA levels detected after cTBS to the motor cortex, without changes in glutamate being observed (Stagg, 2009). Moreover, several studies implicated a contribution of GABAergic neurotransmission in TBS-evoked plasticity (Larson and Munkacsy, 2015). Findings that cTBS lead to decreased numbers in calbindin interneurons (Suppa, 2016) or a report of a modulation of different classes of interneurons after both cTBS and iTBS (Labedi, 2014) adds to the importance of the interneural network in TBS mechanisms. Interestingly, increases in GABA concentrations could be shown after both iTBS and cTBS when some clinical studies reported elevated GABA levels or an influence on marker for GABAergic inhibition (Harrington and Hammond-Tooke, 2015; Vidal-Pineiro, 2015; Dubin, 2016) after iTBS treatment in patients, while also cTBS was shown to increase GABA concentrations in the motor cortex of healthy individuals (Stagg, 2009). However, the attribution of GABAergic interneurons could not be reflected in alterations in total GABA+ content in the scope of our study. Although, there seems to be a cluster with GABA+/tNAA increases in the stimulation area of cTBS, our data did not reach statistical significance within this ROI. Hence, in contrast to previous MRS studies of patient cohorts we could not show GABA alterations after iTBS (Harrington and Hammond-Tooke, 2015; Dubin, 2016).

This surface-based analysis approach for MRSI data provides a suitable method when changes in cortical neurotransmitter concentrations are of interest. Based on previous surface-based PET analyses approaches (Greve, 2014), analysis of cortical metabolites can be done using cortex-based atlases in individual subjects (Desikan, 2006). However, an appropriate MRSI sequence with reliable signal suppression in lipid-rich areas is required. Moreover, this method allows the quantification of several cortical regions simultaneously, which discriminates these investigations from previous MRS studies focusing on the effects of rTMS treatment using single voxel approaches in very selected brain regions.

Some limitations of this study need to be mentioned. While the use of GABA-edited MRSI provides the basis for the quantification of both excitatory and inhibitory neurotransmitters, the GABA signal is prone to artifacts. Hence, the data available was limited to a restricted number of cortical brain regions compared to derived Glx maps. All TRD patients included in these analyses had stable treatment regimens of at least 4 weeks prior to the study inclusion, which remained unchanged in the course of this study. However, an attribution of pharmacological interventions in the derived GABA+ and Glx concentrations cannot be excluded. Moreover, we could not include a group receiving sham treatment due to the limited number in available TRD patients undergoing MRSI. 
medRxiv preprint doi: https://doi.org/10.1101/2022.02.17.22271118; this version posted February 21, 2022. The copyright holder for this preprint (which was not certified by peer review) is the author/funder, who has granted medRxiv a license to display the preprint in All rights reserved. No reuse allowed without permission.

\section{Conclusion}

This study demonstrates a significant increase of GIx/tNAA ratios in the stimulation area of excitatory iTBS treatment of TRD patients. Our findings suggests changes in glutamate metabolism, following excitatory iTBS, to be mediated by reduced inhibition of pyramidal cell, while neurotransmitter concentrations remained stable after inhibitory cTBS on the contralateral hemisphere. These results may help to contribute to a better understanding of neurobiological implications of TBS in TRD patients.

\section{Funding}

This research was funded in whole, or in part by the Austrian Science Fund (FWF) [KLI 551, to S. Kasper] and grant number P 30701 to W. Bogner, the Medical Imaging Cluster of the Medical University of Vienna, and by the grant „Interdisciplinary translational brain research cluster (ITHC) with highfield MR" from the Federal Ministry of Science, Research and Economy (BMWFW), Austria. For the purpose of open access, the author has applied a CC BY public copyright license to any Author Accepted Manuscript version arising from this submission. M.B. Reed is a recipient of a DOC Fellowship of the Austrian Academy of Sciences.

\section{Acknowledgements}

We thank Richard Frey, Gregor Gryglewski, Marius Hienert, Marie Spies, Christoph Kraus, Alexander Kautzky, Arkadiusz Komorowski, Paul Michenthaler and the diploma students of the Neuroimaging Labs (NIL) for medical support. Moreover, we would like to express our gratitude towards Sebastian Ganger, Philipp Moser and Eva Heckova for technical support, and all additional staff involved in the realization of this research.

\section{Conflict of interest}

R. Lanzenberger received travel grants and/or conference speaker honoraria within the last three years from Bruker BioSpin MR and Heel, and has served as a consultant for Ono Pharmaceutical. He received investigator-initiated research funding from Siemens Healthcare regarding clinical research using PET/MR. He is a shareholder of the start-up company BM Health GmbH since 2019. 
medRxiv preprint doi: https://doi.org/10.1101/2022.02.17.22271118; this version posted February 21, 2022. The copyright holder for this preprint (which was not certified by peer review) is the author/funder, who has granted medRxiv a license to display the preprint in All rights reserved. No reuse allowed without permission.

\section{Data availability statement}

Due to data protection laws processed data is available from the authors upon reasonable request. Please contact rupert.lanzenberger@meduniwien.ac.at with any questions or requests. 
medRxiv preprint doi: https://doi.org/10.1101/2022.02.17.22271118; this version posted February 21, 2022. The copyright holder for this preprint (which was not certified by peer review) is the author/funder, who has granted medRxiv a license to display the preprint in

\section{References}

Abdallah CG, Jiang L, De Feyter HM, Fasula M, Krystal JH, Rothman DL, Mason GF, Sanacora G (2014) Glutamate metabolism in major depressive disorder. Am J Psychiatry 171:1320-1327, DOI: 10.1176/appi.ajp.2014.14010067.

Baeken C, Marinazzo D, Wu GR, Van Schuerbeek P, De Mey J, Marchetti I, Vanderhasselt MA, Remue J, Luypaert R, De Raedt R (2014) Accelerated HF-rTMS in treatment-resistant unipolar depression: Insights from subgenual anterior cingulate functional connectivity. World J Biol Psychiatry 15:286-297, DOI: 10.3109/15622975.2013.872295.

Baldinger P, Lotan A, Frey R, Kasper S, Lerer B, Lanzenberger R (2014) Neurotransmitters and electroconvulsive therapy. J ECT 30:116-121, DOI: 10.1097/YCT.0000000000000138.

Bartova L, Dold M, Kautzky A, Fabbri C, Spies M, Serretti A, Souery D, Mendlewicz J, Zohar J, Montgomery S, Schosser A, Kasper S (2019) Results of the European Group for the Study of Resistant Depression (GSRD) - basis for further research and clinical practice. World J Biol Psychiatry 20:427-448, DOI: 10.1080/15622975.2019.1635270.

Berlim MT, van den Eynde F, Tovar-Perdomo S, Daskalakis ZJ (2014) Response, remission and dropout rates following high-frequency repetitive transcranial magnetic stimulation (rTMS) for treating major depression: a systematic review and meta-analysis of randomized, doubleblind and sham-controlled trials. Psychol Med 44:225-239, DOI: 10.1017/S0033291713000512.

Bogner W, Gagoski B, Hess AT, Bhat H, Tisdall MD, van der Kouwe AJ, Strasser B, Marjanska M, Trattnig S, Grant E, Rosen B, Andronesi OC (2014) 3D GABA imaging with real-time motion correction, shim update and reacquisition of adiabatic spiral MRSI. Neuroimage 103:290-302, DOI: 10.1016/j.neuroimage.2014.09.032.

Brennan BP, Admon R, Perriello C, LaFlamme EM, Athey AJ, Pizzagalli DA, Hudson JI, Pope HG, Jr., Jensen JE (2017) Acute change in anterior cingulate cortex GABA, but not glutamine/glutamate, mediates antidepressant response to citalopram. Psychiatry Res 269:916, DOI: 10.1016/j.pscychresns.2017.08.009.

Collaborators C-MD (2021) Global prevalence and burden of depressive and anxiety disorders in 204 countries and territories in 2020 due to the COVID-19 pandemic. Lancet 398:1700-1712, DOI: 10.1016/S0140-6736(21)02143-7.

Croarkin PE, Levinson AJ, Daskalakis ZJ (2011) Evidence for GABAergic inhibitory deficits in major depressive disorder. Neurosci Biobehav Rev 35:818-825, DOI:

10.1016/j.neubiorev.2010.10.002.

Croarkin PE, Nakonezny PA, Wall CA, Murphy LL, Sampson SM, Frye MA, Port JD (2016) Transcranial magnetic stimulation potentiates glutamatergic neurotransmission in depressed adolescents. Psychiatry research Neuroimaging 247:25-33, DOI: 10.1016/j.pscychresns.2015.11.005.

Desikan RS, Segonne F, Fischl B, Quinn BT, Dickerson BC, Blacker D, Buckner RL, Dale AM, Maguire RP, Hyman BT, Albert MS, Killiany RJ (2006) An automated labeling system for subdividing the human cerebral cortex on MRI scans into gyral based regions of interest. Neuroimage 31:968-980, DOI: 10.1016/j.neuroimage.2006.01.021.

Dubin MJ, Mao X, Banerjee S, Goodman Z, Lapidus KA, Kang G, Liston C, Shungu DC (2016) Elevated prefrontal cortex GABA in patients with major depressive disorder after TMS treatment measured with proton magnetic resonance spectroscopy. J Psychiatry Neurosci 41:E37-45, DOI: $10.1503 / j p n .150223$.

Fitzgerald PB, Fountain S, Daskalakis ZJ (2006) A comprehensive review of the effects of rTMS on motor cortical excitability and inhibition. Clin Neurophysiol 117:2584-2596, DOI: 10.1016/j.clinph.2006.06.712.

Gaynes BN, Lux L, Gartlehner G, Asher G, Forman-Hoffman V, Green J, Boland E, Weber RP, Randolph C, Bann C, Coker-Schwimmer E, Viswanathan M, Lohr KN (2020) Defining treatment-resistant depression. Depress Anxiety 37:134-145, DOI: 10.1002/da.22968.

Ge R, Blumberger DM, Downar J, Daskalakis Z, Dipinto AA, Tham JCW, Lam R, Vila-Rodriguez F (2017) Abnormal functional connectivity within resting-state networks is related to rTMS-based 
medRxiv preprint doi: https://doi.org/10.1101/2022.02.17.22271118; this version posted February $21,2022$. The copyright holder for this preprint (which was not certified by peer review) is the author/funder, who has granted medRxiv a license to display the preprint in

All rights reserved. No reuse allowed without permission.

therapy effects of treatment resistant depression: A pilot study. J Affect Disord 218:75-81, DOI: 10.1016/j.jad.2017.04.060.

George MS, Wassermann EM, Williams WA, Callahan A, Ketter TA, Basser P, Hallett M, Post RM (1995) Daily repetitive transcranial magnetic stimulation (rTMS) improves mood in depression. Neuroreport 6:1853-1856, DOI: 10.1097/00001756-199510020-00008.

Greve DN, Svarer C, Fisher PM, Feng L, Hansen AE, Baare W, Rosen B, Fischl B, Knudsen GM (2014) Cortical surface-based analysis reduces bias and variance in kinetic modeling of brain PET data. Neuroimage 92:225-236, DOI: 10.1016/j.neuroimage.2013.12.021.

Grohn H, Gillick BT, Tkac I, Bednarik P, Mascali D, Deelchand DK, Michaeli S, Meekins GD, LefflerMcCabe MJ, MacKinnon CD, Eberly LE, Mangia S (2019) Influence of Repetitive Transcranial Magnetic Stimulation on Human Neurochemistry and Functional Connectivity: A Pilot MRI/MRS Study at 7 T. Frontiers in neuroscience 13:1260, DOI: 10.3389/fnins.2019.01260.

Gunduz-Bruce H, Silber C, Kaul I, Rothschild AJ, Riesenberg R, Sankoh AJ, Li H, Lasser R, Zorumski CF, Rubinow DR, Paul SM, Jonas J, Doherty JJ, Kanes SJ (2019) Trial of SAGE-217 in Patients with Major Depressive Disorder. The New England journal of medicine 381:903-911, DOI: 10.1056/NEJMoa1815981.

Hahn A, Lanzenberger R, Wadsak W, Spindelegger C, Moser U, Mien LK, Mitterhauser M, Kasper S (2010) Escitalopram enhances the association of serotonin-1A autoreceptors to heteroreceptors in anxiety disorders. J Neurosci 30:14482-14489, DOI: 10.1523/JNEUROSCI.2409-10.2010.

Harrington A, Hammond-Tooke GD (2015) Theta Burst Stimulation of the Cerebellum Modifies the TMS-Evoked N100 Potential, a Marker of GABA Inhibition. Plos One 10:DOI: 10.1371/journal.pone.0141284.

Hecht D (2010) Depression and the hyperactive right-hemisphere. Neuroscience research 68:77-87, DOI: 10.1016/j.neures.2010.06.013.

Hnilicova P, Povazan M, Strasser B, Andronesi OC, Gajdosik M, Dydak U, Ukropec J, Dobrota D, Trattnig S, Bogner W (2016) Spatial variability and reproducibility of GABA-edited MEGALASER 3D-MRSI in the brain at 3 T. NMR Biomed 29:1656-1665, DOI: 10.1002/nbm.3613.

Huang YZ, Chen RS, Rothwell JC, Wen HY (2007) The after-effect of human theta burst stimulation is NMDA receptor dependent. Clinical Neurophysiology 118:1028-1032, DOI: 10.1016/j.clinph.2007.01.021.

Huang YZ, Edwards MJ, Rounis E, Bhatia KP, Rothwell JC (2005) Theta burst stimulation of the human motor cortex. Neuron 45:201-206, DOI: 10.1016/j.neuron.2004.12.033.

Ishikawa S, Matsunaga K, Nakanishi R, Kawahira K, Murayama N, Tsuji S, Huang YZ, Rothwell JC (2007) Effect of theta burst stimulation over the human sensorimotor cortex on motor and somatosensory evoked potentials. Clinical Neurophysiology 118:1033-1043, DOI: 10.1016/j.clinph.2007.02.003.

Iwabuchi SJ, Raschke F, Auer DP, Liddle PF, Lankappa ST, Palaniyappan L (2017) Targeted transcranial theta-burst stimulation alters fronto-insular network and prefrontal GABA. Neuroimage 146:395-403, DOI: 10.1016/j.neuroimage.2016.09.043.

Kalueff AV, Nutt DJ (2007) Role of GABA in anxiety and depression. Depress Anxiety 24:495-517, DOI: 10.1002/da.20262.

Kasper S, Cubala WJ, Fagiolini A, Ramos-Quiroga JA, Souery D, Young AH (2021) Practical recommendations for the management of treatment-resistant depression with esketamine nasal spray therapy: Basic science, evidence-based knowledge and expert guidance. World J Biol Psychiatry 22:468-482, DOI: 10.1080/15622975.2020.1836399.

Labedi A, Benali A, Mix A, Neubacher U, Funke K (2014) Modulation of Inhibitory Activity Markers by Intermittent Theta-burst Stimulation in Rat Cortex is NMDA-receptor Dependent. Brain Stimulation 7:394-400, DOI: 10.1016/j.brs.2014.02.010.

Lanzenberger R, Kranz GS, Haeusler D, Akimova E, Savli M, Hahn A, Mitterhauser M, Spindelegger C, Philippe C, Fink M, Wadsak W, Karanikas G, Kasper S (2012) Prediction of SSRI treatment response in major depression based on serotonin transporter interplay between median 
medRxiv preprint doi: https://doi.org/10.1101/2022.02.17.22271118; this version posted February 21, 2022. The copyright holder for this preprint (which was not certified by peer review) is the author/funder, who has granted medRxiv a license to display the preprint in perpetuity.

All rights reserved. No reuse allowed without permission.

raphe nucleus and projection areas. Neuroimage 63:874-881, DOI:

10.1016/j.neuroimage.2012.07.023.

Larson J, Munkacsy E (2015) Theta-burst LTP. Brain Research 1621:38-50, DOI:

10.1016/j.brainres.2014.10.034.

Lewis CP, Port JD, Frye MA, Vande Voort JL, Ameis SH, Husain MM, Daskalakis ZJ, Croarkin PE (2016) An Exploratory Study of Spectroscopic Glutamatergic Correlates of Cortical Excitability in Depressed Adolescents. Front Neural Circuits 10:98, DOI: 10.3389/fncir.2016.00098.

Li CT, Chen MH, Juan CH, Huang HH, Chen LF, Hsieh JC, Tu PC, Bai YM, Tsai SJ, Lee YC, Su TP (2014) Efficacy of prefrontal theta-burst stimulation in refractory depression: a randomized shamcontrolled study. Brain : a journal of neurology 137:2088-2098, DOI: 10.1093/brain/awu109.

Li CT, Huang YZ, Bai YM, Tsai SJ, Su TP, Cheng CM (2019) Critical role of glutamatergic and GABAergic neurotransmission in the central mechanisms of theta-burst stimulation. Hum Brain Mapp 40:2001-2009, DOI: 10.1002/hbm.24485.

Luborzewski A, Schubert F, Seifert F, Danker-Hopfe H, Brakemeier EL, Schlattmann P, Anghelescu I, Colla M, Bajbouj M (2007) Metabolic alterations in the dorsolateral prefrontal cortex after treatment with high-frequency repetitive transcranial magnetic stimulation in patients with unipolar major depression. Journal of Psychiatric Research 41:606-615, DOI: 10.1016/j.jpsychires.2006.02.003.

McIntyre RS, Rosenblat JD, Nemeroff CB, Sanacora G, Murrough JW, Berk M, Brietzke E, Dodd S, Gorwood P, Ho R, losifescu DV, Lopez Jaramillo C, Kasper S, Kratiuk K, Lee JG, Lee Y, Lui LMW, Mansur RB, Papakostas GI, Subramaniapillai M, Thase M, Vieta E, Young AH, Zarate CA, Jr., Stahl S (2021) Synthesizing the Evidence for Ketamine and Esketamine in TreatmentResistant Depression: An International Expert Opinion on the Available Evidence and Implementation. Am J Psychiatry 178:383-399, DOI: 10.1176/appi.ajp.2020.20081251.

Michael N, Gosling M, Reutemann M, Kersting A, Heindel W, Arolt V, Pfleiderer B (2003) Metabolic changes after repetitive transcranial magnetic stimulation (rTMS) of the left prefrontal cortex: a sham-controlled proton magnetic resonance spectroscopy (H-1 MRS) study of healthy brain. European Journal of Neuroscience 17:2462-2468, DOI: 10.1046/j.14609568.2003.02683.x.

Mikellides G, Michael P, Psalta L, Schuhmann T, Sack AT (2021) A Retrospective Naturalistic Study Comparing the Efficacy of Ketamine and Repetitive Transcranial Magnetic Stimulation for Treatment-Resistant Depression. Frontiers in psychiatry 12:784830, DOI: 10.3389/fpsyt.2021.784830.

Pogarell O, Koch W, Popperl G, Tatsch K, Jakob F, Zwanzger P, Mulert C, Rupprecht R, Moller HJ, Hegerl U, Padberg F (2006) Striatal dopamine release after prefrontal repetitive transcranial magnetic stimulation in major depression: preliminary results of a dynamic [123I] IBZM SPECT study. J Psychiatr Res 40:307-314, DOI: 10.1016/j.jpsychires.2005.09.001.

Qi S, Abbott CC, Narr KL, Jiang R, Upston J, McClintock SM, Espinoza R, Jones T, Zhi D, Sun H, Yang X, Sui J, Calhoun VD (2020) Electroconvulsive therapy treatment responsive multimodal brain networks. Hum Brain Mapp 41:1775-1785, DOI: 10.1002/hbm.24910.

Rowland LM, Bustillo JR, Mullins PG, Jung RE, Lenroot R, Landgraf E, Barrow R, Yeo R, Lauriello J, Brooks WM (2005) Effects of ketamine on anterior cingulate glutamate metabolism in healthy humans: a 4-T proton MRS study. Am J Psychiatry 162:394-396, DOI: 10.1176/appi.ajp.162.2.394.

Rush AJ, Trivedi MH, Wisniewski SR, Nierenberg AA, Stewart JW, Warden D, Niederehe G, Thase ME, Lavori PW, Lebowitz BD, McGrath PJ, Rosenbaum JF, Sackeim HA, Kupfer DJ, Luther J, Fava M (2006) Acute and longer-term outcomes in depressed outpatients requiring one or several treatment steps: a STAR*D report. Am J Psychiatry 163:1905-1917, DOI: 10.1176/ajp.2006.163.11.1905.

Salomons TV, Dunlop K, Kennedy SH, Flint A, Geraci J, Giacobbe P, Downar J (2014) Resting-state cortico-thalamic-striatal connectivity predicts response to dorsomedial prefrontal rTMS in major depressive disorder. Neuropsychopharmacology 39:488-498, DOI:

10.1038/npp.2013.222. 
medRxiv preprint doi: https://doi.org/10.1101/2022.02.17.22271118; this version posted February 21, 2022. The copyright holder for this preprint (which was not certified by peer review) is the author/funder, who has granted medRxiv a license to display the preprint in

Sanacora G, Mason GF, Rothman DL, Hyder F, Ciarcia JJ, Ostroff RB, Berman RM, Krystal JH (2003) Increased cortical GABA concentrations in depressed patients receiving ECT. Am J Psychiatry 160:577-579, DOI: 10.1176/appi.ajp.160.3.577.

Sanacora G, Mason GF, Rothman DL, Krystal JH (2002) Increased occipital cortex GABA concentrations in depressed patients after therapy with selective serotonin reuptake inhibitors. Am J Psychiatry 159:663-665, DOI: 10.1176/appi.ajp.159.4.663.

Sanacora G, Treccani G, Popoli M (2012) Towards a glutamate hypothesis of depression: an emerging frontier of neuropsychopharmacology for mood disorders. Neuropharmacology 62:63-77, DOI: 10.1016/j.neuropharm.2011.07.036.

Silberbauer LR, Spurny B, Handschuh P, Klobl M, Bednarik P, Reiter B, Ritter V, Trost P, Konadu ME, Windpassinger M, Stimpfl T, Bogner W, Lanzenberger R, Spies M (2020) Effect of Ketamine on Limbic GABA and Glutamate: A Human In Vivo Multivoxel Magnetic Resonance Spectroscopy Study. Frontiers in psychiatry 11:549903, DOI: 10.3389/fpsyt.2020.549903.

Spindelegger C, Lanzenberger R, Wadsak W, Mien LK, Stein P, Mitterhauser M, Moser U, Holik A, Pezawas L, Kletter K, Kasper S (2009) Influence of escitalopram treatment on 5-HT 1A receptor binding in limbic regions in patients with anxiety disorders. Mol Psychiatry 14:10401050, DOI: $10.1038 / \mathrm{mp} .2008 .35$.

Spurny B, Heckova E, Seiger R, Moser P, Klobl M, Vanicek T, Spies M, Bogner W, Lanzenberger R (2019) Automated ROI-Based Labeling for Multi-Voxel Magnetic Resonance Spectroscopy Data Using FreeSurfer. Frontiers in molecular neuroscience 12:28, DOI: 10.3389/fnmol.2019.00028.

Spurny B, Vanicek T, Seiger R, Reed MB, Klobl M, Ritter V, Unterholzner J, Godbersen GM, Silberbauer LR, Pacher D, Klug S, Konadu ME, Gryglewski G, Trattnig S, Bogner W, Lanzenberger R (2021) Effects of SSRI treatment on GABA and glutamate levels in an associative relearning paradigm. Neuroimage 117913 , DOI: 10.1016/j.neuroimage.2021.117913.

Stagg CJ, Wylezinska M, Matthews PM, Johansen-Berg H, Jezzard P, Rothwell JC, Bestmann S (2009) Neurochemical effects of theta burst stimulation as assessed by magnetic resonance spectroscopy. J Neurophysiol 101:2872-2877, DOI: 10.1152/jn.91060.2008.

Suppa A, Huang YZ, Funke K, Ridding MC, Cheeran B, Di Lazzaro V, Ziemann U, Rothwell JC (2016) Ten Years of Theta Burst Stimulation in Humans: Established Knowledge, Unknowns and Prospects. Brain Stimulation 9:323-335, DOI: 10.1016/j.brs.2016.01.006.

Taylor M, Murphy SE, Selvaraj S, Wylezinkska M, Jezzard P, Cowen PJ, Evans J (2008) Differential effects of citalopram and reboxetine on cortical Glx measured with proton MR spectroscopy. J Psychopharmacol 22:473-476, DOI: 10.1177/0269881107081510.

Tremblay S, Beaule V, Proulx S, de Beaumont L, Marjanska M, Doyon J, Pascual-Leone A, Lassonde M, Theoret $\mathrm{H}$ (2013) Relationship between transcranial magnetic stimulation measures of intracortical inhibition and spectroscopy measures of GABA and glutamate+glutamine. J Neurophysiol 109:1343-1349, DOI: 10.1152/jn.00704.2012.

Vidal-Pineiro D, Martin-Trias P, Falcon C, Bargallo N, Clemente IC, Valls-Sole J, Junque C, PascualLeone A, Bartres-Faz D (2015) Neurochemical Modulation in Posteromedial Default-mode Network Cortex Induced by Transcranial Magnetic Stimulation. Brain Stimulation 8:937-944, DOI: 10.1016/j.brs.2015.04.005.

Yue L, Xiao-Lin H, Tao S (2009) The effects of chronic repetitive transcranial magnetic stimulation on glutamate and gamma-aminobutyric acid in rat brain. Brain Research 1260:94-99, DOI: 10.1016/j.brainres.2009.01.009. 